\title{
Growth rates of larval and juvenile bigeye scad Selar crumenophthalmus in captivity
}

\author{
Aaron Welch", Ronald Hoenig, John Stieglitz, Zach Daugherty, Bruno Sardenberg, Sasa Miralao, Dan Farkas \\ and Dan Benetti
}

\begin{abstract}
Growth rates of larval and juvenile bigeye scad Selar crumenophthalmus reared in captivity were studied. The results are presented, discussed, and compared to wild S. crumenophthalmus and other pelagic fish. S. crumenophthalmus are a small pelagic carangid fish of circumtropical distribution. Larvae were reared in a modified mesocosm system and sampled daily for growth. Larvae grew to a mean size of $4.74 \mathrm{~cm}$ (Standard Length) and $1.30 \mathrm{~g}$ by 45 days post hatch (dph). Larval length-at-age was best described by the exponential equation $Y=1.966 \mathrm{e}^{0.0704 t}$. For juvenile growth trials, 1940 fish were stocked into four $2.5 \mathrm{~m}^{3}$ cylindro-conical tanks at two different densities (262 fish $\mathrm{m}^{-3}$ and 120 fish $\mathrm{m}^{-3}$ ) and reared from $45 \mathrm{dph}$ to subadult stage. Fish were sampled daily for growth. No statistically significant differences in growth or survival were detected between tanks. Mean length and weight at $141 \mathrm{dph}$ was $13.24 \mathrm{~cm}$ (Total Length) and $25.20 \mathrm{~g}$. Juvenile length-at-age was best described by the Von Bertalanffy Growth Model equation $L_{t}=27.75\left(1-e^{-0.03(t-1.57)}\right)$. Weight-at-age was best described by a linear equation $W_{t}=1.7313 x+12.4662$. The exponent of the length-weight equation was 3.14. In addition to providing the first published description of larviculture and juvenile growout techniques for S. crumenophthalmus, this study contains the first published data on this species' larval growth and directly confirms estimates of S. crumenophthalmus juvenile growth done by other researchers using indirect techniques such as otolith daily growth increment and frequency distribution analysis.
\end{abstract}

Keywords: Larviculture; Length-at-age; Mean daily growth increment; Von Bertalanffy Growth Model; Weight-at-age

\section{Introduction}

Bigeye scad Selar crumenophthalmus (Bloch) are a small pelagic, schooling fish of circum-tropical distribution (e.g. Dalzell and Penaflor 1989; Clarke and Privitera 1995; Mohammed and Rennie 2003; Hendiarti et al. 2005; Roos et al. 2007). Members of the Carangidae family, S. crumenophthalmus are an important forage fish for high trophic level predators, are highly valued as food in Asian and Pacific cultures, and are used as bait by recreational and commercial fishermen all over the world (Clarke and Privitera 1995; Honebrink 2000; Roos et al. 2007).

S. crumenophthalmus support a number of important fisheries throughout the world. In Hawaii more than 500 metric tons of S. crumenophthalmus (known locally as akule and hahalalu) are harvested each year for local consumption (Stevens 2004). In parts of the Indonesian and the Philippine archipelagos S. crumenophthalmus catches account for 3 to $15 \%$ of the annual small pelagic fish

* Correspondence: awelch@rsmas.miami.edu

University of Miami, 4600 Rickenbacker Causeway, Miami, FL 33149, USA harvest (Dalzell and Penaflor 1989; Hendiarti et al. 2005). Around Reunion Island in the Indian Ocean, fishers take more than 35 metric tons of S. crumenophthalmus (known locally as atule) a year using hand lines and beach seines (Roos et al. 2007). In Florida and the Caribbean there is very little reliable data on the magnitude of S. crumenophthalmus (known locally as goggle eye) harvests but anecdotal evidence indicates that landings are significant, especially for use as live bait. In the Caribbean, live S. crumenophthalmus are the favored bait of the pelagic long line fishing fleet. Individual long line vessels take as many as 12,000 fish to sea per trip in large $(\sim 8500 \mathrm{l})$ live wells where they are used to target tunas (Thunnus spp.) and other high value fish (Capt. Don Landry, personal communication, 20 April 2010). In Florida, S. crumenophthalmus were formerly harvested as a food fish, largely for sale in the Asian market. The fishery, however, was based on unsustainable purse-seining practices and by the mid-1990s stocks had declined over large portions of the species' 
range. As the stocks declined, the food-fish fishery was largely forgotten and the S. crumenophthalmus became increasingly valuable as live bait for recreational fishermen. Today S. crumenophthalmus in Florida retail for \$ 100 for a dozen live fish or more (Capt. Butch Constable, personal communication, 15 October 2008).

Wild S. crumenophthalmus exhibit rapid growth rates, reaching a fork length $\left(L_{\mathrm{f}}\right)$ of approximately 20 to $25 \mathrm{~cm}$ in one year (Dalzell and Penaflor 1989; Roos et al. 2007) and have been observed with a $L_{\mathrm{f}}$ of more $28 \mathrm{~cm}$ (Ralston and Williams 1988). They are partial spawners, and have been estimated to release 92,000 eggs per spawn (Clarke and Privitera 1995). In the wild, spawning occurs over an extended period during warm months (Kawamoto 1973; Tobias 1987; Clarke and Privitera 1995; Roos et al. 2007). S. crumenophthalmus are not generally believed to survive more than one spawning season, although a small number of animals are reported to live as long as three years (Kawamoto 1973; Ralston and Williams 1988). Feeding is largely nocturnal and planktonic animals such as euphasiids and fish larvae are favored prey items (Roux and Conand 2000).

In this paper the growth rates of larval and juvenile S. crumenophthalmus reared in captivity are compared with the growth rates of wild $S$. crumenophthalmus and other wild and hatchery-reared small pelagic fish, especially carangids. We also compare length-weight data for both wild and captive juvenile S. crumenophthalmus and describe larviculture and juvenile growout techniques for the species.

\section{Materials and methods}

\section{Broodstock capture, maturation and spawning}

All the fish used in this study were reared in captivity from eggs obtained from wild broodstock. All broodstock fish used for this study were captured in waters approximately five nautical miles east-southeast of Key Biscayne, Florida, in the vicinity of Fowey Rocks (National Data Buoy Center Station FWYF1), latitude $25.590 \mathrm{~N} 80.097 \mathrm{~W}$ and held at the University of Miami Experimental Hatchery (UMEH).

Broodstock fish were held in four $4.5 \mathrm{~m}^{3}$ cylindro-conical tanks connected to a single recirculating filtration system utilizing UV, mechanical (broken glass) and biological filtration. Each tank had its own egg collector. Broodstock fish were conditioned to spawn in their tanks by maintaining water temperature at $28-30^{\circ} \mathrm{C}$, a level that corresponds to the upper end of the ambient temperature range experienced in south Florida coastal waters during the S. crumenophthalmus spawning season (NODC National Ocean Data Center 2010). Natural light was provided through a $95 \%$ reflective cloth. Water exchange was approximately $20 \%$ per day. Ammonia $\left(\mathrm{NH}_{4}\right)$ was kept below $0.5 \mathrm{mg} \mathrm{l}^{-1}$. Dissolved Oxygen was maintained at or above saturation. Photoperiod was not manipulated.
The eggs used in this study came from two spawning events that were induced using hormone injections. The first group of fish $(n=20)$ was injected with Luteinizing Hormone-Releasing Hormone analogue (LHRH-a) at a dosage of 25 to $50 \mu \mathrm{g} \mathrm{kg}^{-1}$. The second group of fish $(n=20)$ was injected with Human Chorionic Gonadotropin (HCG) at a rate of $1000 \mathrm{IU} \mathrm{kg}^{-1}$. Both groups were segregated in separate maturation tanks. The fish were not sexed prior to injection. The fish injected with LHRH-a produced an estimated 54,400 eggs with a fertilization rate of $82.4 \%$ and an average diameter of $735 \mu \mathrm{m}$. The HCG injected fish produced an estimated 62,440 eggs with a fertilization rate of $96.7 \%$ and an average diameter of $744 \mu \mathrm{m}$. Eggs were pooled in a single incubator and the hatch rate was approximately $80 \%$.

\section{Larval rearing}

Approximately 71,000 yolk-sac larvae at $1 \mathrm{dph}$ were stocked into a $1.8 \mathrm{~m}^{3}$ flat-bottomed larval-rearing tank supplied with $1 \mu \mathrm{m}$ filtered seawater for this study. The early stage larval rearing protocols used in this study relied on a modified greenwater system adapted from other authors (Liao et al. 2001; Papandroulakis et al. 2002; Partridge et al. 2003; Palmer et al. 2007). A mixture of 50\% Isochrysis galbana and 50\% Nannochloropsis oculata was maintained in the larviculture tank at a density of $\sim 400,000$ cells $\mathrm{ml}^{-1}$. Due to a shortage of live algae, small amounts of commercially prepared non-viable I. galbana and $N$. oculata concentrates (NutrOcean, Inc., Rimouski, Quebec) were added on an as-needed basis to maintain the desired concentration of microalgae in the larval rearing tanks. The percentage of concentrate substitution never rose above 50\%. Enriched s-type rotifers (Brachionus rotundiformus) were maintained in the tank at a density of 20-30 rotifers $\mathrm{ml}^{-1}$ via daily additions.

Beginning at $17 \mathrm{dph}$ the culture was transitioned from a modified greenwater system to an intensive system adapted from Benetti et al. (2008). Water exchange was increased (ultimately reaching $1000 \%$ per day), enriched instar-2 Artemia were provided using a pulse feeding method, and algal and rotifer densities were allowed to drop to zero. Commercially prepared weaning feeds were provided along with the live feeds beginning at $22 \mathrm{dph}$. By $35 \mathrm{dph}$ the fish were fully weaned onto commercially prepared feeds.

A 24-hour light photoperiod was used to rear the larvae through $6 \mathrm{dph}$ using aquarium lighting. At $7 \mathrm{dph}$ the photoperiod was changed to 18 hours light and 6 hours dark. Beginning at $16 \mathrm{dph}$ the light period was reduced by one to one and a half hours hour per day until the photoperiod was entirely natural ( $\sim 11$ hours light and 13 hours dark) at $20 \mathrm{dph}$. Natural light was provided through an $80 \%$ shade cloth. Temperatures in the larviculture tank ranged from 25 to $28^{\circ} \mathrm{C}$ and dissolved oxygen 
(DO) levels were maintained above saturation (from 7 to $14 \mathrm{mg} \mathrm{l}^{-1}$ ) throughout the trial.

\section{Juvenile growout}

At $45 \mathrm{dph}$ all fish used for this study were transferred from their larval rearing tank to four $2.5 \mathrm{~m}^{3}$ cylindro-conical growout tanks. All four tanks were connected to a common recirculating filtration system utilizing UV, mechanical (broken glass) and biological filtration. Two tanks were stocked with 655 fish each (262 fish $\mathrm{m}^{-3}$ ) and two were stocked with 305 fish each (120 fish $\left.\mathrm{m}^{-3}\right)$. The mean length and weight of the fish stocked was $5.25 \mathrm{~cm}$ Total Length $\left(L_{\mathrm{t}}\right)$ and $1.30 \mathrm{~g}$ in all tanks. Otohime EP1 and EP2 feeds (Aquatic Enterprise Co., Sarawak, Malaysia) were fed to the juvenile S. crumenophthalmus until $95 \mathrm{dph}$. Zeigler Marine Grower "Gold" $3.0 \mathrm{~mm}$ feed (44\% crude protein, 18\% crude fat) (Zeigler Bros, Inc., Gardners PA, USA) was provided until the end of this trial at four and a half months post hatch. Natural light was provided through a 95\% reflective cloth. Oxygen was maintained at or above saturation for the duration of this trial. Temperature was maintained between 20 and $22^{\circ} \mathrm{C}$, although on two occasions winter cold fronts caused water temperatures in the system to drop as low as $16^{\circ} \mathrm{C}$. Water exchange was approximately $20 \%$ per day. Ammonia $\left(\mathrm{NH}_{4}\right)$ was kept below $0.5 \mathrm{mg} \mathrm{l}^{-1}$. Fish were fed ad libitum twice a day. Aquaculture performance variables, including feed conversion rates (FCR), survival rates, and growth rates, were determined individually for each tank. The growout trial in the four $2.5 \mathrm{~m}^{3}$ tanks was ended at $141 \mathrm{dph}$ because the filtration equipment was unable to handle the rapidly increasing bio-load and the fish were outgrowing the tanks. The fish were moved to a single, $12 \mathrm{~m}^{3}$ growout tank with flow-through, $10 \mu \mathrm{m}$ filtered seawater.

\section{Data collection and analysis}

10 larvae per day were randomly sampled for length from 3 to $24 \mathrm{dph}(n=220)$ when net avoidance behavior made it difficult to capture fish. Between $24 \mathrm{dph}$ and 45 $\mathrm{dph}$ all samples were obtained by weighing and measuring otherwise healthy fish that died due to wall strikes $(n=14)$. This method of sampling was also used throughout the growout phase of the trial $(n=190)$. Fish that died of disease or unknown causes were not measured. This method of sampling was chosen because the events that triggered wall strikes were apparently random and because net avoidance behavior rendered it impossible to catch individual fish without creating excessive stress among the other fish in the tank. Additionally, fish were randomly sacrificed at $45 \mathrm{dph}(n=25)$ and $141 \mathrm{dph}(n=44)$ to supplement existing data and estimate mean size.

A group of wild juvenile S. crumenophthalmus $(n=33)$ was captured in order to establish a length-weight relationship that could be used as a baseline for comparison with captive-reared fish. These fish were captured using the same methodology that was used to capture broodstock, but were caught in shallow waters more immediately adjacent to Key Biscayne, Florida. Fish were stored on ice and transported back to laboratories at the University of Miami where they were weighed and measured. Fish were captured in July and September of 2009 and likely represent the result of spring and summer spawns from the same year.

A Von Bertalanffy Growth Model (VBGM) was developed in $R$ ( $R$ Development Core Team, 2011) using the Fisheries Stock Assessment methods platform, a software toolbox for fisheries modeling (Ogle 2010). Best fit models for linear and non-linear relationships were developed and plotted using Newton least squares methods within $\mathrm{R}$ and Microsoft Excel 2010. Different mean growth rates and other aquaculture performance metrics between tanks were tested for statistical significance using a Students t-test with results considered significant at $\mathrm{p} \leq 0.05$. No outliers (runts) were excluded from the data set.

\section{Results}

\section{Larval growth}

Larval S. crumenophthalmus grew to a mean weight of $1.30 \mathrm{~g}$ and $4.74 \mathrm{~cm}$ Standard Length $\left(L_{\mathrm{s}}\right)$ by $45 \mathrm{dph}$. Larvae had a mean length of $2.23 \mathrm{~mm}$ at hatching. Size heterogeneity within the cohort increased over time (Figure 1). The survival rate from yolk-sac larvae to $45 \mathrm{dph}$ was approximately $2.74 \%$. Metamorphosis was complete for all fish by $45 \mathrm{dph}$. Length-at-age $\left(L_{\mathrm{s}}\right)$ to $45 \mathrm{dph}$ was best described by the exponential equation

$$
L_{\mathrm{s}}=1.966 \mathrm{e}^{0.0704 t}\left(\mathrm{r}^{2}=0.93\right)
$$

Mean daily growth for a given age was calculated by subtracting the mean hatch length $(2.23 \mathrm{~mm})$ from the mean length and then dividing by the relevant number of days. This resulted in a predicted mean Absolute Growth Rate (AGR) $\left(\mathrm{mm} \mathrm{day}^{-1}\right)$ of $1.03 \mathrm{~mm} \mathrm{day}^{-1}\left(L_{\mathrm{s}}\right)$ to $45 \mathrm{dph}$ (Table 1 ).

Ontogenetic development proceeded rapidly (Figure 2). The embryonic yolk sac disappeared by the end of 1 $\mathrm{dph}$ and the associated oil globule was absorbed by $2 \mathrm{dph}$. Exogenous feeding and development of the very large lens that characterizes the eyes of adult S. crumenophthalmus was evident as early as $2 \mathrm{dph}$. Swim bladder development began between 4 and $7 \mathrm{dph}$. Digestive tract folding began at approximately $7 \mathrm{dph}$. Flexion began at $11 \mathrm{dph}$ and was complete in all fish by $18 \mathrm{dph}$. Metamorphosis was complete for all fish by $45 \mathrm{dph}$, when the juveniles were transferred to growout tanks. 


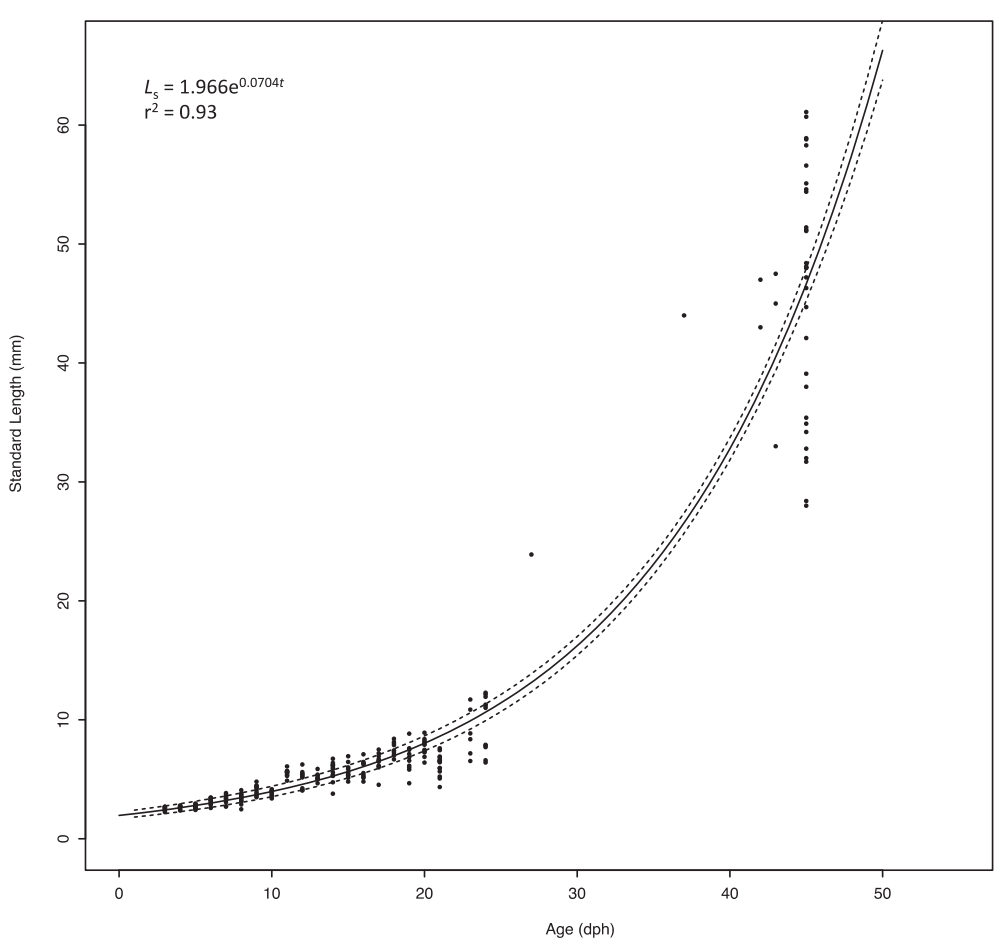

Figure 1 The length-at-age, non-linear regression model (solid line) for $S$. crumenophthalmus larvae $(n=259)$ ages $1-45$ dph. Dashed lines represent the $95 \%$ upper and lower confidence intervals calculated using bootstrapped growth parameters. The model is based on Standard Length $\left(L_{s}\right)$.

\section{Juvenile growth}

Growth rates during the juvenile growout study (46 to $141 \mathrm{dph})$ were not significantly different in any of the tanks $(\mathrm{p}>0.05)$. Fish grew to a mean size of $13.24 \mathrm{~cm}$ $\left(L_{\mathrm{t}}\right)$ and $25.20 \mathrm{~g}$ by $141 \mathrm{dph}$. Specific growth rate (SGR) (\% body weight day ${ }^{-1}$ ) was $3.08 \%$ based on mean weight at $141 \mathrm{dph}$. There were also no significant differences in aquaculture performance between the tanks $(p>0.05)$.
FCRs in the tanks ranged between 1.30 and 1.62 with an overall FCR for the trial of 1.48. Survival rates in the tanks ranged from 88.1 to $92.1 \%$ with an overall mean survival rate for the trial of $89.1 \%$ (Table 2).

Because there were no statistical differences in aquaculture performance between tanks, growth curves and length-weight relationships were calculated using pooled data broken down into one-week (7 day) increments.

Table 1 Growth rates for S. crumenophthalmus and selected carangid, clupeid, and engraulid larvae

\begin{tabular}{|c|c|c|c|}
\hline Species & Location & Growth rate & Reference \\
\hline Bigeye Scad & Aquaculture & $0.31 \mathrm{~mm}$ day $^{-1}\left(L_{s}\right) 1$ to $24 \mathrm{dph}$ & Current study \\
\hline \multirow[t]{2}{*}{ Selar crumenophthalmus } & & $1.80 \mathrm{~mm}$ day $^{-1}\left(L_{s}\right) 24$ to $45 \mathrm{dph}$ & \\
\hline & & $1.03 \mathrm{~mm} \mathrm{day}^{-1}\left(L_{s}\right) 1$ to $45 \mathrm{dph}$ & \\
\hline Horse Mackerel Trachurus declivis & Tasmanian Coast, Australia & $0.24-0.29 \mathrm{~mm}$ day $^{-1}\left(L_{s}\right)$ to $15 \mathrm{dph}$ & Jordan (1994) \\
\hline Rough Scad Trachurus Iathami & Brazilian Bight, Brazil & $0.41 \mathrm{~mm} \mathrm{day}^{-1}$ (Body length) to $80 \mathrm{dph}$ & Katsuragawa and Ekau (2003) \\
\hline Atlantic Bumper Chloroscombrus chrysurus & $\begin{array}{l}\text { Southern Gulf of } \\
\text { Mexico, Mexico }\end{array}$ & $0.12 \mathrm{~mm}$ to $0.17 \mathrm{~mm}$ day $^{-1}\left(L_{s}\right)$ to $50 \mathrm{dph}$ & $\begin{array}{l}\text { Sanchez-Ramirez and } \\
\text { Flores-Coto (1998) }\end{array}$ \\
\hline Jack Mackerel Trachurus japonicus & East China Sea, Japan & $\sim 0.6 \mathrm{~mm} \mathrm{day}^{-1}$ (Body length) to $78 \mathrm{dph}$ & Xie et al. (2005) \\
\hline Florida Pompano Trachinotus carolinus & Aquaculture & $0.22-0.35 \mathrm{~mm}$ day $^{-1}\left(L_{f}\right)$, to $20 \mathrm{dph}$ & Riley et al. (2009) \\
\hline Amberjack Seriola dumerili & Aquaculture & $0.82 \mathrm{~mm}$ day $^{-1}\left(L_{t}\right)$, to $40 \mathrm{dph}$ & Papandroulakis et al. (2005) \\
\hline Atlantic Menhaden Brevoortia tyrannus & North Carolina Coast, USA & $0.22-0.35 \mathrm{~mm}$ day $^{-1}\left(L_{\mathrm{t}}\right)$ to $20 \mathrm{dph}$ & Warlen (1992) \\
\hline Japanese Anchovy Engraulis japonicus & Kuroshio Current, Japan & $0.68 \mathrm{~mm}$ day $^{-1}\left(L_{t}\right)$ to $40 \mathrm{dph}$ & Aoki and Miyashita (2000) \\
\hline Pacific Sardine Sardinops sagax sagax & Peru Current, Peru & $0.7-0.8 \mathrm{~mm}$ day $^{-1}\left(L_{t}\right)$ to $15 \mathrm{dph}$ & $\begin{array}{l}\text { Butler and Rojas de } \\
\text { Mendiola (1985) }\end{array}$ \\
\hline
\end{tabular}




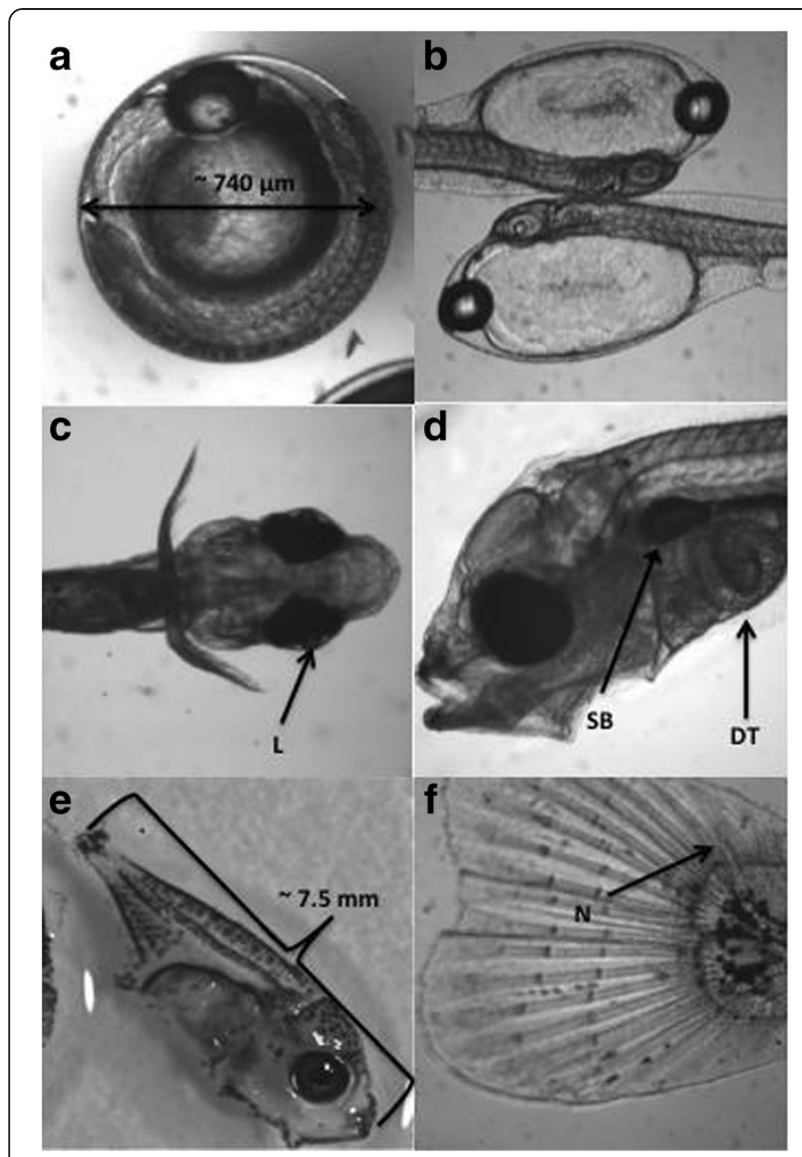

Figure 2 S. crumenophthalmus embryonic and larval development. (a-f) Larval development of S. crumenophthalmus. (a) fertilized egg approximately 3 hours prior to hatching; (b) yolk-sac larvae at $1 \mathrm{dph}$; (c) larvae at $2 \mathrm{dph}$ with prominent lens $(\mathrm{L})$ readily visible; (d) larvae at $7 \mathrm{dph}$ with prominent swim bladder (SB) and digestive tract (DT); (e) 18 dph post-flexion larvae; (f) tail of an 18 dph post-flexion larvae with upturned notochord (N).

Table 2 Selected growth and aquaculture performance parameters for captive juvenile $S$. crumenophthalmus

\begin{tabular}{|c|c|}
\hline Absolute growth (g) $\Delta \mathrm{G}=\mathrm{W}_{2}-\mathrm{W}_{1}$ & 23.90 \\
\hline Absolute growth rate $\left(\right.$ g day $\left.^{-1}\right) A G R=\left(W_{2}-W_{1}\right) /\left(t_{2}-t_{1}\right)$ & 0.25 \\
\hline Relative growth $R G=\left(\mathrm{W}_{2}-\mathrm{W}_{1}\right) / \mathrm{W}_{1}$ & 18.38 \\
\hline Relative growth rate $R G R=\left(W_{2}-W_{1}\right) / W_{1}\left(t_{2}-t_{1}\right)$ & 0.19 \\
\hline Instantaneous growth rate $\left(\right.$ g day $\left.^{-1}\right) \mid G R=\left(\ln W_{2}-\ln W_{1}\right) /\left(t_{2}-t_{1}\right)$ & 0.031 \\
\hline Specific growth rate $\left(\right.$ g day $\left.^{-1}\right) S G R=100 *\left(\ln W_{2}-\ln W_{1}\right) /\left(t_{2}-t_{1}\right)$ & 3.08 \\
\hline Mean weight $(\mathbf{g})( \pm$ SD) at $141 \mathrm{dph}$ & $25.20(6.49)$ \\
\hline Mean length $(\mathrm{cm})\left(L_{t}\right)( \pm$ SD) at $141 \mathrm{dph}$ & $13.24(1.03)$ \\
\hline $\begin{array}{l}\text { Feed conversion ratio } \mathrm{FCR}=\text { Feed offered/total } \\
\text { biomass gain }\end{array}$ & 1.48 \\
\hline Survival (\%) from 46 to $141 \mathrm{dph}$ & 89.1 \\
\hline
\end{tabular}

We did not calculate separate curves for male and female fish because there was no basis for observing sexual dimorphism. Length-at-age for captive juvenile big eye scad was best described by the VBGM equation

$$
L_{\mathrm{t}}=27.75\left(1-\mathrm{e}^{-0.03(t-1.57))}\right)\left(\mathrm{r}^{2}=0.92\right)
$$

(Figure 3). A linear relationship also provided a good fit for the length-at-age data and was described by the equation

$$
L_{\mathrm{t}}=0.6868 \mathrm{x}-0.7543\left(\mathrm{r}^{2}=0.91\right) \text {. }
$$

A linear relationship provided the best fit for the weight-atage data and was described by the equation

$$
W_{\mathrm{t}}=1.7313 \mathrm{t}-12.4662\left(\mathrm{r}^{2}=0.60\right) \text {. }
$$

(Figure 4). The length-weight relationship for captive reared S. crumenophthalmus was best described by the equation

$$
W_{\mathrm{t}}=0.008 L_{t}^{3.14}\left(\mathrm{r}^{2}=0.95\right)
$$

(Figure 5). No statistically significant differences were noted between the length-weight relationships of wild and captive fish.

\section{Discussion}

\section{Larval growth}

The survival rate to $45 \mathrm{dph}$ was relatively low (2.74\%) in this study. Other species with more established larviculture technologies often have much higher survival rates over a comparable period of ontogenetic development. Cohorts of cobia (Rachycentron canadum) reared at the UMEH, for example, often exhibit survival rates of $15 \%$ or more (Benetti et al. 2010a). There is no published data on the growth rates of larval S. crumenophthalmus available in the scientific literature so there is no basis for comparing the growth of the larvae studied here with wild larvae. The larvae studied here, however, exhibited an AGR (mm day ${ }^{-1}$ ) greater than the reported growth rates of many other wild and hatchery-reared clupeid, engraulid and carangid species (Table 1). The growth rates of larval S. crumenophthalmus appeared to reach an inflection point around $24 \mathrm{dph}$. Up to $24 \mathrm{dph}$ the mean AGR was $0.31 \mathrm{~mm}$ day $^{1}$. Between 24 and $45 \mathrm{dph}$ the rate increased to a mean of $1.80 \mathrm{~mm} \mathrm{day}^{-1}$ (Figure 1). This increase in growth rate was accompanied by an increase in the swimming ability of the fish that was evidenced by the fact that sampling after $24 \mathrm{dph}$ became extremely difficult due to net avoidance behavior. Similar improvements in the burst swimming speed of other species of pelagic fish larvae have been observed at comparable points in their ontogenetic development (Masuda 2006). 


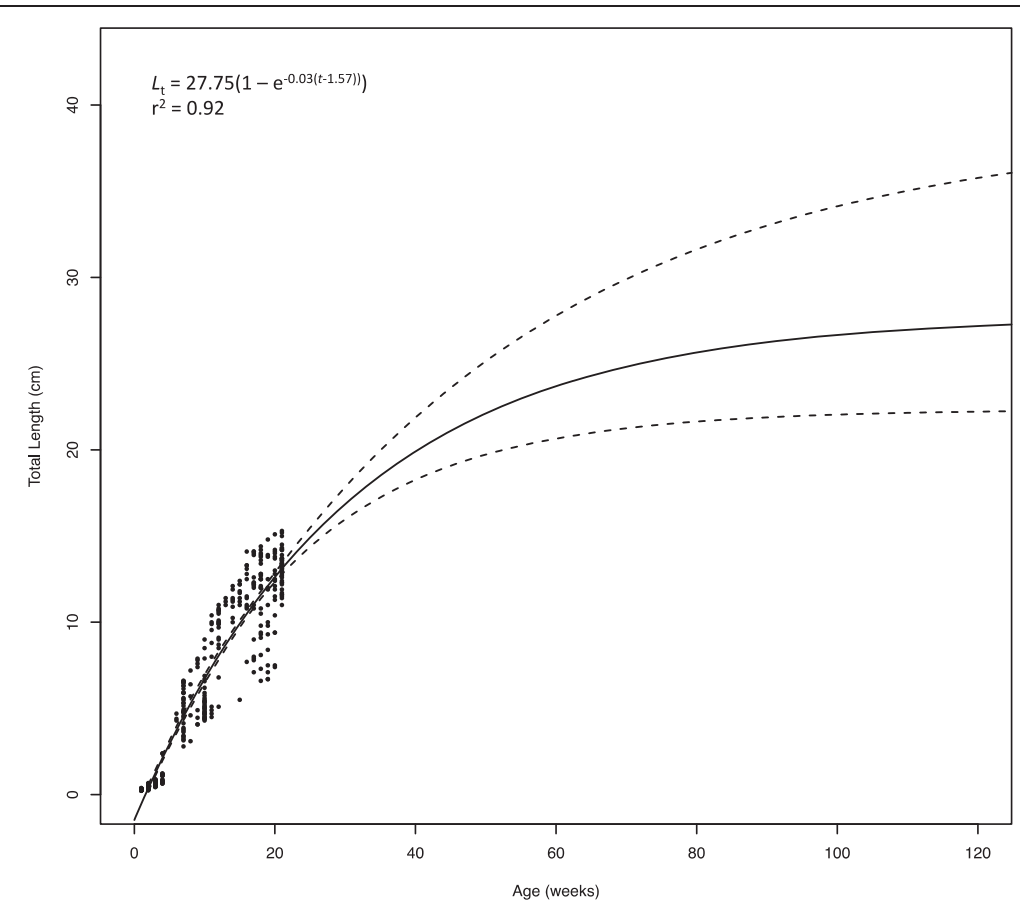

Figure 3 Von Bertalanffy Growth Model (solid line) for S. crumenophthalmus $(n=493)$ with $95 \%$ upper and lower confidence intervals using bootstrapped growth parameters (dashed line) for age 1-21 week fish extrapolated to 120 weeks. The model is based on Total Length $\left(L_{\mathrm{t}}\right)$.

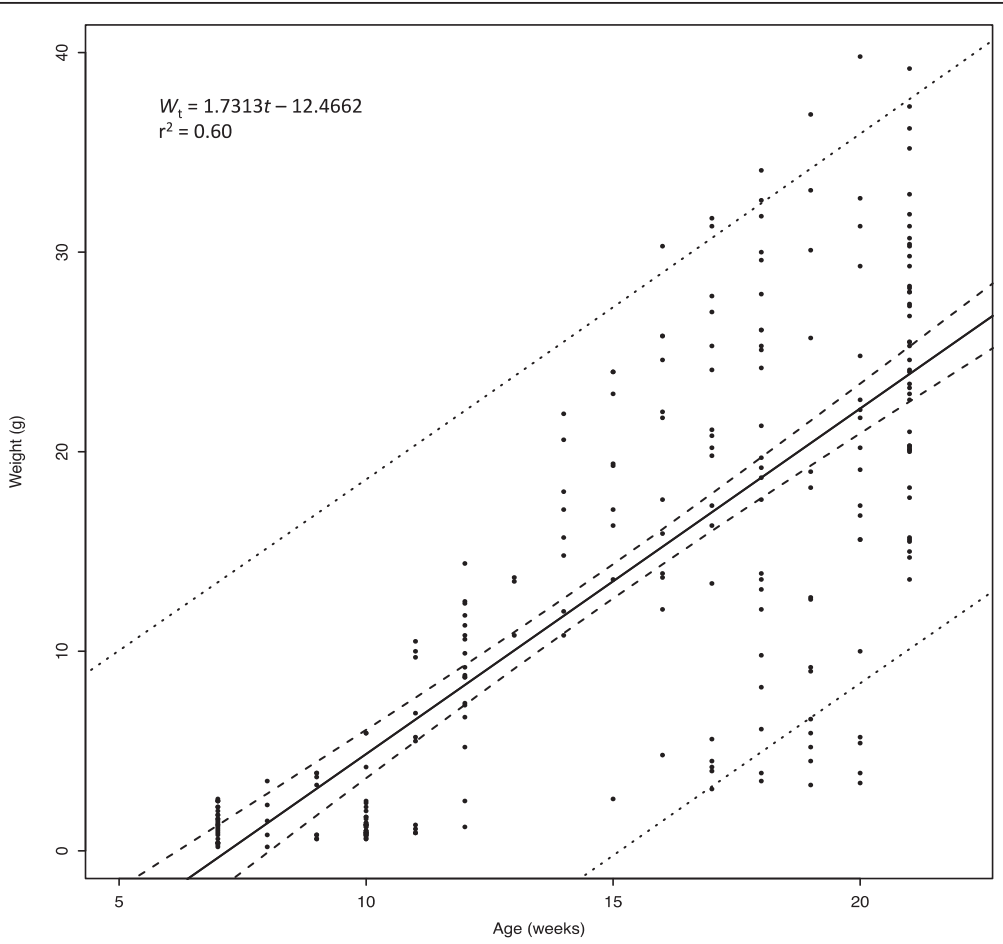

Figure 4 Weight-at-age $\left(W_{t}\right)$ linear regression model (solid line) for S. crumenophthalmus $(n=259)$ for age 7 to 21 week fish with $95 \%$ upper and lower confidence bounds (dashed line) and $95 \%$ upper and lower prediction bounds (dotted line). 


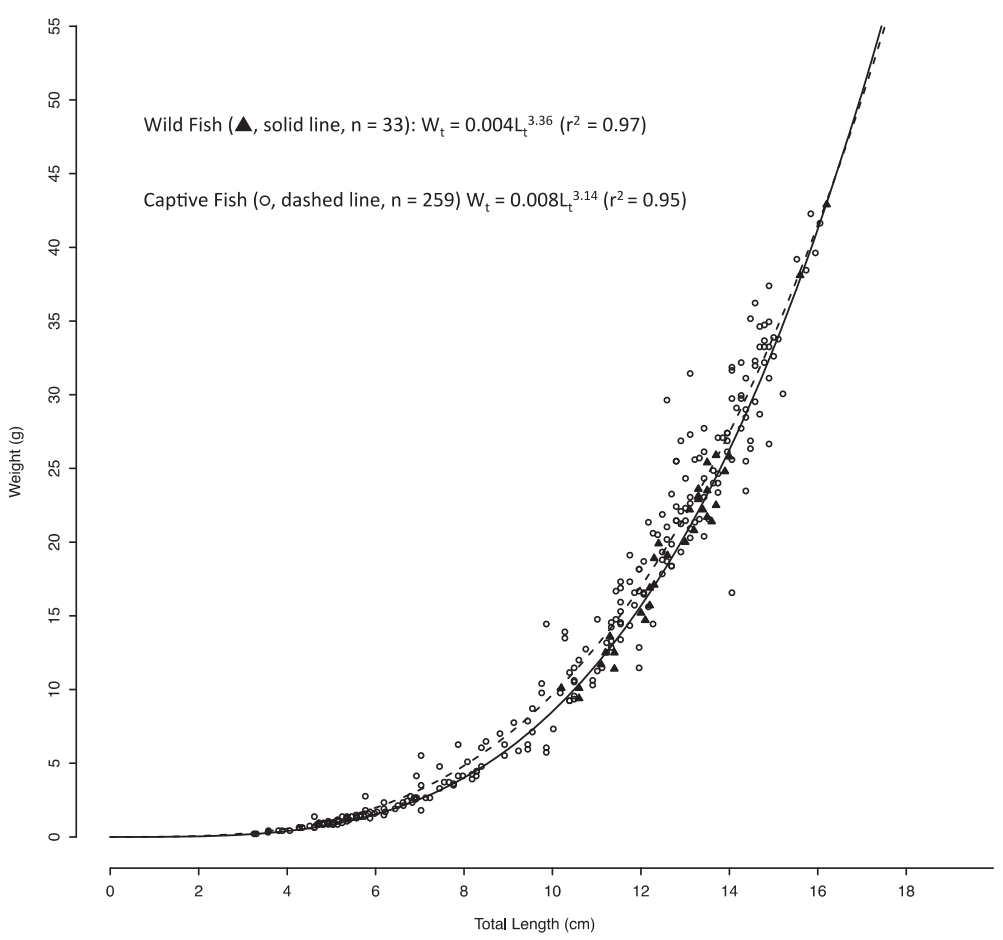

Figure 5 Weight-at-length non-linear relationship of wild $(\leftarrow$, solid line, $n=33)$ and captive $(0$, dashed line, $n=259)$ S. crumenophthalmus. The model is based on weight-at-age $\left(W_{t}\right)$ and total length $\left(L_{t}\right)$.

\section{Juvenile growth}

Both a VBGM and a linear model provided a good fit for the data. The linear model provided a good fit for the data $\left(r^{2}=0.91\right)$ because the experiment ended at the sub-adult phase of development, before the asymptotic phase of the growth curve was reached. VBGM parameters were within the lower end of the range of values that have been estimated for wild S. crumenophthalmus by researchers using indirect sampling techniques such as otolith daily growth increment and frequency distribution analysis.

The VBGM for the captive reared S. crumenophthalmus studied here had an asymptotic length $\left(L_{\infty}\right)$ of $27.75 \mathrm{~cm}$ $\left(L_{\mathrm{t}}\right)$ and a coefficient of growth $(K)$ of 0.03 week $^{-1}$. Wild $S$. crumenophthalmus have been reported to have $L_{\infty}$ values ranging from 26.5 to $31.6 \mathrm{~cm}\left(L_{\mathrm{t}}\right)$ and $K$ values ranging from 0.28 to 2.06 year $^{-1}$ (Dalzell and Penaflor 1989; Garcia and Duarte 2006; Roos et al. 2007). Additionally, the VBGM developed here predicts that captive fish will reach a $L_{\mathrm{t}}$ of $14.9 \mathrm{~cm}$ at 6 months, $19.0 \mathrm{~cm}$ at 9 months, and $21.8 \mathrm{~cm}$ at one year. This is only slightly lower than the length-at-age values observed in the wild: Dalzell and Penaflor (1989) reported that S. crumenophthalmus in the Phillipines reach $23 \mathrm{~cm}\left(L_{\mathrm{f}}\right)$ in a year; Ralston and Williams (1988) report that Pacific Ocean S. crumenophthalmus attain $24.3 \mathrm{~cm}\left(L_{\mathrm{t}}\right)$ of growth by $330 \mathrm{dph}$; and Roos et al. (2007) report that Indian Ocean S. crumenophthalmus grow to $22.0 \mathrm{~cm}\left(L_{\mathrm{f}}\right)$ in one year.
Because temperature is known to be a major driver of fish growth and metabolism (Schmidt-Nielsen 1997) we believe that the temperatures maintained in the tanks $\left(20-22^{\circ} \mathrm{C}\right)$ were suboptimal for juvenile $S$. crumenophthalmus growth and likely contributed to the lower growth rates. Even relatively small deviations from optimal temperatures can have large consequences for growth rates. Sun et al. (2006), for example, compared the growth rates of juvenile cobia (Rachycentron canadum) reared at 23 and $27^{\circ} \mathrm{C}$ and found that the fish reared at the higher temperature grew $44 \%$ faster. High stocking densities are also known to negatively affect the growth of cultured fish and may have been a contributing factor here (e.g. Faulk et al. 2007; Benetti et al. 2010b).

Even given their slower growth relative to their wild counterparts, the juvenile fish studied here exhibited a mean SGR (3.08\%) that was higher than many other species of tropical and subtropical juvenile fish commonly reared in captivity. Cobia (Rachycentron canadum), mutton snapper (Lutjanus analis), amberjack (Seriola dumerili), and red drum (Sciaenops ocellatus), for example, exhibit SGRs ranging from 0.32 to $3.31 \%$ at comparable stages in their development (Skaramuca et al. 2001; Benetti et al. 2002; 2010b; Burr et al. 2006). Juvenile S. crumenophthalmus growth rates are not, however, extraordinary for tropical and subtropical pelagic fish. Juvenile mahi mahi (Coryphaena hippurus) cultured in captivity, for example, have been observed to have SGRs between 4 and 10\% (Benetti et al. 1995). 
Weight-at-age was difficult to describe mathematically due to the continued presence of very small fish (runts) in the tanks that appeared to weight the regression downward. Fish under $10 \mathrm{~g}$ were still being sampled as late as $140 \mathrm{dph}$. This resulted in considerable heterogeneity in the weight-at-age data. The best fit was a linear relationship $\left(r^{2}=0.60\right)$. This size-heterogeneity may have been the result of fish that were genetically predisposed to slow growth but were able to remain alive longer than they would have been able to as part of a wild population subject to size-specific mortality processes (Sogard 1997). Additionally, size-specific competition may have reduced access to feed for the smaller fish and further depressed their growth, especially in later stages of the growout trial.

The exponent of the length-weight equation $(b)$ for captive $S$. crumenophthalmus was calculated to be 3.14. This is lower than the $b$ values calculated for wild juvenile S. crumenophthalmus. The exponent of the length-weight equation generated from our sample of wild juvenile S. crumenophthalmus $(\mathrm{n}=33)$ was 3.36 and Roos et al. (2007) found that the exponent of the length-weight equation ranged from 3.22 to 3.37 depending on the structure of the sample (male, female, or mixed). This was a surprising result. Captive reared fish tend to have a higher $\mathrm{b}$ value and condition factor than their wild counterparts, indicating that they are more robust and spherical in appearance and exhibit a more allometric growth pattern their wild counterparts (e.g. Blaxter 1988; Benetti et al. $1995 ; 2002 ; 2010 b)$. The lower $b$ value of the fish in this study departs from this trend. We believe that the continued presence of runts in the tank likely skewed this result downward.

Continued presence of runts is a characteristic of populations of fish reared in an aquaculture setting and this phenomenon was clearly seen here. Because many of the largest fish sampled in this trial, however, exhibited sizes that appeared more "normal" we believe that had the runts been removed from the data set as outliers we would have generated growth curves that more closely matched those presented by researchers working with wild fish.

\footnotetext{
Abbreviations

AG: Absolute growth $\left(\Delta G=W_{2}-W_{1}\right)$; $A G R$ : Absolute growth rate $\left(A G R=\left(W_{2}-W_{1}\right)\right.$ ) $\left.\left(\mathrm{t}_{2}-\mathrm{t}_{1}\right)\right)$; DO: Dissolved oxygen; Dph: Days post hatch; FCR: Feed conversion rate ( $F C R=$ Feed Offered/Total Biomass Gain); HCG: Human chorionic gonadotropin; IGR: Instantaneous growth rate $\left(I G R=\left(\ln W_{2}-\operatorname{lnW}_{1}\right) /\left(t_{2}-t_{1}\right)\right) ; L_{f}$. Fork length; $L_{s}$ : Standard length; $L_{t}:$ Total length; $L_{\infty}:$ Asymptotic length; LHRH-a: Luteinizing hormone-releasing hormone analogue; $R G$ : Relative growth $\left(R G=\left(W_{2}-W_{1}\right) / W_{1}\right)$; RGR: Relative growth rate $\left(R G R=\left(W_{2}-W_{1}\right) W_{1}\left(t_{2}-t_{1}\right)\right) ; S D$ : Standard deviation; SGR: Specific growth rate $\left(S G R=100 *\left(\ln W_{2}-\operatorname{InW}_{1}\right) /\left(t_{2}-t_{1}\right)\right) ;$ VBGM: Von Bertalanffy Growth Model; $W_{t}$ : Weight-at-age.
}

\section{Competing interests}

The authors declare that they have no competing interests.

\section{Authors' contributions}

AW was the lead author of this manuscript and coordinated all aspects of the research described here. $\mathrm{RH}$ and JS helped develop the broodstock transport and maturation techniques described here, helped conceive of the larviculture techniques described here, assisted in the design of the recirculating system described here, and helped edit the MS. ZD performed the statistical analysis. $\mathrm{BS}, \mathrm{SM}$, and DF coordinated the husbandry of the fish during the juvenile growout portion of this research and assisted with statistical analysis and data collection. DB assisted in designing all aspects of this study and was the primary editor of this MS. All authors read and approved the final manuscript.

\section{Acknowledgements}

This work was funded by the NOAA Saltonstall-Kennedy Program Grant Number NA09NMF4270072 and the authors are indebted to NOAA for their continued support of the University of Miami Aquaculture Program. Additionally, the authors thank all of the graduate students and volunteers at the UMEH who helped care for the fish that were the subject of this study, especially Drew Davis.

Received: 8 June 2013 Accepted: 13 November 2013 Published: 25 November 2013

\section{References}

Aoki I, Miyashita K (2000) Dispersal of larvae and juveniles of Japanese anchovy Engraulis japonicus in the Kuroshio Extension and Kuroshio-Oyashio transition regions, western North Pacific Ocean. Fish Res 49(2):155-164

Benetti D, Iversen E, Ostrowski A (1995) Growth rates of captive dolphin, Coryphaena hippurus, in Hawaii. Fish Bull 93:152-157

Benetti D, Matera J, Stevens O, Alarcon J, Feeley M, Rotman F, Minemoto Y, Banner-Stevens G, Fanke J, Zimmerman S, Eldridge L (2002) Growth, survival, and feed conversion rates of hatchery-reared mutton snapper lutjanus analis cultured in floating net cages. J World Aquacult Soc 33(3):349-357

Benetti D, Sardenberg B, Welch A, Hoenig R, Orhun M, Zink I (2008) Intensive larval husbandry and fingerling production of cobia Rachycentron canadum. Aquaculture 281:22-27

Benetti D, Sardenberg B, Hoenig R, Welch A, Stieglitz J, Miralao S, Farkas D, Brown P, Jory D (2010a) Cobia (Rachycentron canadum) hatchery-to-market aquaculture technology: recent advances at the University of Miami Experimental Hatchery (UMEH). R Braz Zootec 39:60-67, supl. especial

Benetti D, O'Hanlon B, Rivera J, Welch A, Maxey C, Orhun R (2010b) Growth rates of cobia (Rachycentron canadum) cultured in open ocean cages in the Caribbean. Aquaculture 302:195-201

Blaxter J (1988) Pattern and variety in development. In: Hoar W, Randall D (eds) Fish Physiology, vol. 11a. Academy Press, New York

Burr G, Li P, Goff J, Gatlin D, Grisdale-Helland B, Helland S (2006) Evaluation of growth performance and whole-body composition of juvenile hybrid striped bass morone chrysops $x$ morone saxatilis and red drum sciaenops ocellatus fed high-protein and high-lipid diets. J World Aquacult Soc 37(4):421-430

Butler J, Rojas de Mendiola B (1985) Growth of Larval Sardines Off Peru. CalCoFI Rep 26:113-118

Clarke T, Privitera L (1995) Reproductive biology of two Hawaiin pelagic carangid fishes, the bigeye scad, Selar crumenophthalmus, and the round scad, Decapturus macarellus. Bull Mar Sci 56(1):33-47

Dalzell P, Penaflor G (1989) The fisheries biology of the big-eye scad, Selar crumenophhalmus (Bloch) in the Philipines. Asian Fish Sci 3:115-131

Faulk C, Kaiser J, Holt G (2007) Growth and survival of larval and juvenile cobia Rachycentron canadum in a recirculating raceway system. Aquaculture 270:149-157

Garcia C, Duarte L (2006) Length-based estimates of growth parameters and mortality rates of fish populations of the Caribbean Sea. J Appl Ichthyol 22:193-200

Hendiarti N, Suwarso AE, Amri K, Andiastuti R, Sachoemar S, Wahyono I (2005) Seasonal variation of pelagic fish catch around Java. Oceanogr 18(4):112-123

Honebrink R (2000) A review of the biology of the family Carangidae, with emphasis on species found in Hawaiian waters. DAR Technical Report 20-01. Hawaii Department of Land and Natural Resources, Division of Aquatic Resources. Project Report No. 20-01. , Hawaii

Jordan A (1994) Age, Growth, and Back-calculated Birthdate Distributions of Larval Jack Mackerel, Trachurus declivis (Pisces:Carangidae), from Eastern Tasmanian Coastal Waters. Aust J Mar Freshwater Res 45:19-33

Katsuragawa M, Ekau W (2003) Distribution, growth and mortality of young rough scad, Trachurus lathami, in south-eastern Brazilian Bight. J Appl Ichthyol 19(1):21-28

Kawamoto P (1973) Management investigation of the akule or bigeye scad (Trachurops crumenophthalmus) (Bloch). Hawaii Division of Fish and Game, Project Report No. H-4-r, Honolulu, Hawaii 
Liao IC, Su HM, Chang EY (2001) Techniques in finfish larviculture in Taiwan. Aquaculture 200:1-31

Masuda R (2006) Ontogeny of anti-predator behavior in hatchery-reared jack mackerel Trachurus japonicas larvae and juveniles: patchiness formation, swimming capability, and interaction with jellyfish. Fish Sci 72(6):1225-1235

Mohammed E, Rennie J (2003) Grenada and the Grenadines: reconstructed fisheries catches and fishing effort, 1942-2001. Fish Cent Res Rep 11(6):67-94

NODC (National Ocean Data Center) (2010) Coastal Water Temperature Guide (CWTG)., Available via http://www.nodc.noaa.gov/dsdt/cwtg/index.html. Cited 25 April 25, 2010

Ogle D (2010) FSA: a R software package for fisheries stock assessment methods. Northland College, Ashland, Wisconsin, USA., Available via http://www. ncfaculty.net/dogle/fishR/. Cited 15 Jan 2011

Palmer P, Burke M, Palmer C, Burke J (2007) Developments in controlled green-water larval culture technologies for estuarine fishes in Queensland, Australia and elsewhere. Aquaculture 272:1-21

Partridge G, Jenkins G, Frankish K (2003) Hatchery manual for the production of snapper (Pagrus auratus) and black bream (Acanthopagrus butcheri). Western Australian Maritime Training Centre, Challenger TAFE, Fremantle

Papandroulakis N, Divanach P, Kentouri M (2002) Enhanced biological performance of intensive sea bream (Sparus aurata) larviculture in the presence of phytoplankton with long photophase. Aquaculture 204:45-63

Papandroulakis N, Mylonas C, Maingot E, Divanach P (2005) First results of greater amberjack (Seriola dumerili) larval rearing in mesocosm. Aquaculture 250:155-161

R Development Core Team (2011) R: a Language and Environment for Statistical Computing. R Foundation for Statistical Computing, Vienna, Austria, Available via http://www.r-project.org/. Cited 15 Jan 2011

Ralston S, Williams H (1988) Depth distribution, growth and mortality of deep-slope fishes from the Mariana Archipelago. Southwest Fisheries Center, National Oceanographic and Atmospheric Administration, National Marine Fisheries Service Technical Memorandum No. 113. NOAA, Honolulu

Riley K, Weirich C, Cerino D (2009) Development and growth of hatchery-reared larval Florida pompano (Trachinotus carolinus). Fish Bull 107(3):318-328

Roos D, Roux O, Conand F (2007) Notes on the biology of the bigeye scad, Selar crumenophthalmus (Carangidae) around Reunion Island, southwest Indian Ocean. Scienta Marina 71(1):137-144

Roux O, Conand F (2000) Feeding habits of the bigeye scad, Selar crumenophthalmus (Carangidae) in La Reunion Island waters (South-Western Indian Ocean). Cybium 24(2):173-179

Sanchez-Ramirez M, Flores-Coto C (1998) Growth and mortality of larval atlantic bumper chloroscombrus chrysurus (Pisces:Carangidae) in the Southern Gulf of Mexico. Bull Mar Sci 63(2):295-303

Schmidt-Nielsen K (1997) Animal Physiology: Adaptation and Environment, 5th edn. University Press, Cambridge

Skaramuca B, Kozul V, Teskeredzic E, Bolotin J, Onofri V (2001) Growth rate of tank-reared Mediterranean amberjack, Seriola dumerili (Riso 1810) fed on three different diets. J Appl Ichthyol 17(3):130-133

Sogard S (1997) Size selective mortality in the juvenile stage of teleost fishes: a review. Bull Mar Sci 60(3):1129-1157

Stevens M (2004) Big-eye scad: akule; Mackerel scad: opelu; Final Report. Seafood Watch Seafood Report. Monterey Bay Aquarium, 2004., Available via http://www.montereybayaquarium.org/cr/cr_seafoodwatch/content/ media/MBA_SeafoodWatch_HIScadsAkuleOpeluReport.pdf. Cited 22 Feb 2011

Sun L, Chen H, Huang L, Wang Z, Yap Y (2006) Growth and energy budget of juvenile cobia Rachycentron canadum relative to ration. Aquaculture 257:214-220

Tobias W (1987) Resource evaluation of the bigeye scad Selar Crumenophthalmus in the insular shelf waters around St. Croix, US Virgin Islands. Proc Gulf Caribb Fish Inst 40:82-98

Warlen S (1992) Age, growth, and size distribution of larval Atlantic Menhaden off North Carolina. Trans Am Fish Soc 121:588-598

Xie S, Watanabe Y, Saruwatari T, Masuda R, Yamashita Y, Sassa C, Konishi Y (2005) Growth and morphological development of sagittal otoliths of laval and early juvenile Trachurus japonicus. J Fish Biol 66(6):1704-1719

doi:10.1186/2193-1801-2-634

Cite this article as: Welch et al:: Growth rates of larval and juvenile bigeye scad Selar crumenophthalmus in captivity. SpringerPlus $20132: 634$

\section{Submit your manuscript to a SpringerOpen ${ }^{\circ}$ journal and benefit from:}

- Convenient online submission

- Rigorous peer review

- Immediate publication on acceptance

- Open access: articles freely available online

- High visibility within the field

- Retaining the copyright to your article

Submit your next manuscript at $\gg$ springeropen.com 